American Journal of Applied Sciences 6 (9): 1637-1646, 2009

ISSN 1546-9239

(C) 2009 Science Publications

\title{
P-Glycoprotein-Mediated Efflux and Drug Sequestration in Lysosomes Confer Advantages of K562 Multidrug Resistance Sublines to Survive Prolonged Exposure to Cytotoxic Agents
}

\author{
Nathupakorn Dechsupa and Samlee Mankhetkorn \\ Laboratory of Physical Chemistry, Molecular and Cellular Biology, \\ Department of Radiologic Technology, Faculty of Associated Medical Sciences, \\ Center of Excellence for Molecular Imaging, Chiang Mai University, Chiang Mai 50200 Thailand
}

\begin{abstract}
Problem statement: Cellular drug resistance to anticancer agents is major obstacle in cancer chemotherapy and the mechanisms by which these MDR cells possess for protecting themselves to survive prolonged exposure to cytotoxic agents still debating. The study aimed to clarify the role of P-glycoprotein (Pgp) and enhanced drug sequestration in lysosomes to confer the multidrug resistance K562 cells with varied degree of Pgp expression. Approach: Erythromyelogenous leukemic K562 and its corresponding Pgp-over expression K562/adr $(\mathrm{RF}=26.5)$ and $\mathrm{K} 562 / 10000(\mathrm{RF}=39.6)$ cells were used. The transport of intrinsic fluorescence molecules including acridine orange and pirarubicin across plasma membrane of living cells was performed by using spectrofluorometric and flow cytometric analysis. Results: Pirarubicin passively diffused through the plasma membrane of K562, K562/adr and K562/10000 cells with the same values of $\mathrm{k}_{+}=3.4 \pm 0.3 \mathrm{pL}$. $\mathrm{s}^{-1}$.cell ${ }^{-1}$. Similar results were found for acridine orange, which passively diffused through plasma membrane of these cell lines about 30-fold faster than pirarubicin. The mean rate of Pgp-mediated efflux coefficient $\left(\mathrm{k}_{\mathrm{a}}\right)$ of pirarubicin was equal to $2.6 \pm 0.9 \mathrm{pL} . \mathrm{s}^{-1}$.cell ${ }^{-1}$ for $\mathrm{K} 562 / \mathrm{adr}$ and $4.7 \pm 1.0 \mathrm{pL} \cdot \mathrm{s}^{-1}$.cell ${ }^{-1}$ for K562/10000 cells. The Pgp-mediated efflux of acridine orange could not be determined for K562/adr cells while an enhancement of exocytosis in K562/10000 cells was characterized. The acridine orange exhibited antiproliferative activity and $\mathrm{IC}_{50}$ for $\mathrm{K} 562$, K562/adr and $\mathrm{K} 562 / 10000$ cells was $447 \pm 40$, $715 \pm 19$ and $1,719 \pm 258 \mathrm{nM}$, respectively. Cytotoxicity of acridine orange was increased by 2 -fold in the presence of and $25 \mathrm{nM}$ monensin. Conclusion: The results clearly demonstrated for the first time that by using the same methods and cell lines. The predominant cellular defense mechanism determined in multidrug resistant cells depends upon the nature of molecular probes used. As molecular probe, pirarubicin clearly showed that the Pgp-mediated efflux of drug play as predominant mechanism while AO clearly demonstrated the role of drug sequestration in lysosomes following an enhance exocytosis in both MDR sublines.
\end{abstract}

Key words: Multidrug Resistance (MDR), P-glycoprotein (Pgp), Acridine Orange (AO), Drug sequestration in lysosomes, Pirarubicin

\section{INTRODUCTION}

Multidrug Resistance (MDR) of tumor cells to anticancer agents remains a major cause of failure in cancer therapy. MDR is frequently associated with a decreased intracellular accumulation of anticancer drugs due to an overexpression of MDR protein transporters including P-glycoprotein $(\mathrm{Pgp})^{[1]}, \mathrm{MRP}^{[2]}$ and lung resistance related protein ${ }^{[3]}$. In fact MDR phenomenon is always multifactorial. The biochemical and physiological changes other than an overexpression of MDR protein transporters especially an altered $\mathrm{pH}$ gradient across different cellular compartments in particular for acidic organelles of MDR cells was reported ${ }^{[4,5]}$. Studies have shown that the lysosomes entrapped following an enhance exocytosis of weak base anticancer drugs was proposed as a factor that favors a reduced their intracellular accumulation thus their efficiency ${ }^{[6]}$. Despite many studies over recent years, the role of MDR protein

Corresponding Author: Samlee Mankhetkorn, Laboratory of Physical Chemistry, Molecular and Cellular Biology, Department of Radiologic Technology, Faculty of Associated Medical Sciences, Center of Excellence for Molecular Imaging, Chiang Mai University, Chiang Mai 50200 Thailand Tel: 66-53949305 Fax: 66-53213218 
transporters and the sequestration in acidic vesicles following an enhance exocytosis of drugs on conveying drug resistance phenomenon were never studied in the same MDR cell lines. Especially for the MDR cells that have different degrees of drug resistance by using the same methods of MDR cell selection.

Recently we selected MDR cells with Pgp overexpression by exposing the K562/adr to a repetition of fixed adriamycin concentrations (100, 300 and $10000 \mathrm{nM}$ ) in a culture medium. We reported that (i) the MDR1 mRNA levels and the resistance factor (RF) increased with increase in the concentration of adriamycin used for MDR cell selection and (ii) the efficiency of Pgp-mediated efflux was proportional to the RF and the MDR1 mRNA levels ${ }^{[7]}$.

In this study, we used the same K562/adr (RF = 14) and $\mathrm{K} 562 / 10000(\mathrm{RF}=33)$ cell lines as models for investigating the kinetics of uptake, kinetics of active efflux and drug sequestration in lysosomes by using Acridine Orange (AO), in comparison with pirarubicin. $\mathrm{AO}$ is an intrinsic fluorescent molecule and is known as a lysosomotropic agent. It is frequently used to examine the luminal $\mathrm{pH}$ of intracellular acidic organelles (notably lysosome $)^{[8-11]}$. Because AO is a poor substrate of Pgp but efficiently entrapped in lysosomes, therefore it is a suitable probe use for investigating the role of drug sequestration in lysosomes. Contrary to $\mathrm{AO}$, pirarubicin is a good substrate of Pgp and is used as molecular probe for measuring the efficiency of Pgp mediated-efflux of drugs out of MDR cells.

\section{MATERIALS AND METHODS}

Drugs and chemicals: Adriamycin and pirarubicin were kindly provided by Prof. Arlette Garnier-Suillerot, Laboratoire de Physicochimie Biomoleculaire et Cellulaire, UPRES A 7034 CNRS, UFR Santé Medicines et Biologie Humaine, Bobigny, University de Paris Nord. Tetrazolium salt (3-(4, 5-dimethyl-2thiazolyl)-2, 5diphenyl-2H-tetrazolium bromide (MTT)) was from Amresco. Monensin was from Sigma.

Adriamycin and pirarubicin stock solutions were prepared in double-distilled water, just before using. Concentrations were spectrophotometrically determined by diluting stock solutions in water to approximately $10 \mu \mathrm{M}$ and using $\varepsilon_{480}=11,500 \mathrm{M}^{-1} \mathrm{~cm}^{-1}$. A stock solution of MTT was prepared by dissolving $5 \mathrm{mg}$ MTT $\mathrm{mL}^{-1}$ in HEPES-Na ${ }^{+}$buffer and filtering through a $0.22 \mu \mathrm{m}$ filter and stored at $4^{\circ} \mathrm{C}$.

All experiments were performed using HEPES-Na ${ }^{+}$ buffer which consisting of $20 \mathrm{mM}$ HEPES buffer plus $132 \mathrm{mM} \mathrm{NaCl}, 3.5 \mathrm{mM} \mathrm{KCl}, 1 \mathrm{mM} \mathrm{CaCl}_{2}$ and $1.5 \mathrm{mM}$ $\mathrm{MgCl}_{2}, \mathrm{pH} 7.25$ at $37^{\circ} \mathrm{C}$.
Cell culture and cytotoxicity assay: The human erythromyelogenous leukemic, K562 and its Pgp-over expression $\mathrm{K} 562 / \mathrm{adr}^{[12,13]}$ were routinely cultured in RPMI 1640 medium supplemented with $10 \%$ fetal calf serum (Gibco Biocult Ltd.). For assays, a culture was initiated at $5 \times 10^{5}$ cells per $\mathrm{mL}$ to have cells in the exponential growth phase; the cells were used $24 \mathrm{~h}$ later for all series of experiments, when the culture had grown to approximately $8 \times 10^{5}$ cells per mL. Cell viability was assessed by trypan blue exclusion. The number of cells was determined by haemocytometer.

The cytotoxicity assay was performed as follows: $5 \times 10^{4}$ cells per $\mathrm{mL}$ were incubated in the presence of various THP concentrations. The viability of cells was determined by MTT-reduction. The $\mathrm{IC}_{50}$ (conc. of compound that inhibited cell growth by $50 \%$, when measured at $72 \mathrm{~h}$ ) was determined by plotting the percentage of cell growth inhibition versus the concentration of compound. A Resistance Factor (RF) was defined as the $\mathrm{IC}_{50}$ of resistant cells divided by the $\mathrm{IC}_{50}$ of sensitive cells. The RF of K562/adr and K562/10000 cells was equal to 26.5 and 39.6, respectively.

Selection of MDR cells: Adriamycin-resistant K562/10000 subline was selected and characterized as previously described $^{[6]}$. Briefly, K562/adr cells were continuously exposed to $10 \mu \mathrm{M}$ adriamycin in the culture medium for three-times with the interval time of $72 \mathrm{~h}$. The MDR cells were maintained in a fresh RPMI 1640 medium without doxorubicin for three passages before using.

Theoretical approach for intracellular $\mathbf{p H}\left(\mathrm{pH}_{\mathrm{i}}\right)$ and luminal $\mathbf{p H}\left(\mathbf{p H}_{\mathrm{v}}\right)$ of lysosome determination: $\mathrm{AO}$ is a basic molecule $\left(\mathrm{pKa}\left(-\mathrm{NH}_{3}^{+} /-\mathrm{NH}_{2}\right)=9.4\right)$. In an aqueous solution at a given $\mathrm{pH}$, it equilibrates in positive charge $\left(\mathrm{DH}^{+}\right)$and neutral $\left(\mathrm{D}^{\circ}\right)$ forms as indicated in reaction:

$$
\mathrm{DH}^{+} \leftrightharpoons \mathrm{D}^{\circ}+\mathrm{H}^{+}
$$

In the presence of cells, only $\mathrm{D}^{\circ}$ passively diffuses through plasma membrane into cytoplasm and intracellular organelles. In a steady state, the $\mathrm{D}^{\circ}$ form equilibrates between the extracellular $\left(\mathrm{D}_{\mathrm{e}}^{\circ}\right)$, intracellular $\left(\mathrm{D}^{\circ}{ }_{\mathrm{i}}\right)$ and lysosomal $\left(\mathrm{D}^{\circ}{ }_{\mathrm{v}}\right)$ compartments: $\mathrm{D}^{\circ}{ }_{\mathrm{e}} \Leftrightarrow \mathrm{D}^{\circ}{ }_{\mathrm{I}} \Leftrightarrow \mathrm{D}^{\circ}{ }_{\mathrm{v}}$. In fact, the dissociated constant is the same in each compartment, can be written as the following expression:

$$
\mathrm{K}_{\mathrm{a}}=\frac{\left(\left[\mathrm{D}^{0}\right]_{\mathrm{i}}\left[\mathrm{H}^{+}\right]_{\mathrm{i}}\right)}{\left[\mathrm{DH}^{+}\right]_{\mathrm{i}}}=\frac{\left(\left[\mathrm{D}^{0}\right]_{\mathrm{e}}\left[\mathrm{H}^{+}\right]_{\mathrm{e}}\right)}{\left[\mathrm{DH}^{+}\right]_{\mathrm{e}}}
$$


The $\mathrm{pH}_{\mathrm{i}}$ can be determined using the Eq. 1:

$$
\mathrm{pH}_{\mathrm{e}}-\mathrm{pH}_{\mathrm{i}}=\Delta \mathrm{pH}=-\log \frac{\left[\mathrm{DH}^{+}\right]_{\mathrm{e}}}{\left[\mathrm{DH}^{+}\right]_{\mathrm{i}}}
$$

where, $\left[\mathrm{H}^{+}\right]_{\mathrm{i}}$ and $\left[\mathrm{H}^{+}\right]_{\mathrm{e}}$ are the concentrations of protons and $\left[\mathrm{DH}^{+}\right]_{i}$ and $\left[\mathrm{DH}^{+}\right]_{\mathrm{e}}$ are the concentrations of positively charged forms of $\mathrm{AO}$ in intracellular and extracellular compartments, respectively.

In a solution at $\mathrm{pH} 7.25$, which is the value of the intracellular of most cells, AO is found in $1 \%$ of neutral and $99 \%$ of positive charged forms. The total concentration of $\mathrm{AO}$ is the concentration of neutral and charged forms found in cytoplasm $\left(\mathrm{C}_{\mathrm{i}}\right)$ and extracellular $\left(\mathrm{C}_{\mathrm{e}}\right)$ compartment and can be written as follows:

$\mathrm{C}_{\mathrm{i}}=\mathrm{DH}_{\mathrm{i}}^{+}+\mathrm{D}_{\mathrm{i}}^{0} \cong \mathrm{DH}_{\mathrm{i}}^{+}$

$\mathrm{C}_{\mathrm{e}}=\mathrm{DH}_{\mathrm{e}}^{+}+\mathrm{D}_{\mathrm{e}}^{0} \cong \mathrm{DH}_{\mathrm{e}}^{+}$

In the first approximation, we replaced $\left[\mathrm{DH}^{+}\right]_{\mathrm{i}}$ and $\left[\mathrm{DH}^{+}\right]_{\mathrm{e}}$ with $C_{i}$ and $C_{e}$, respectively, in Eq. (1) which becomes:

$\Delta \mathrm{pH}=\log \frac{\left[\mathrm{C}_{\mathrm{i}}\right]}{\left[\mathrm{C}_{\mathrm{e}}\right]}$

In our experiments, the $\mathrm{pH}_{\mathrm{e}}$ is equal to 7.25 then $\mathrm{pH}_{\mathrm{i}}$ can be determined:

$$
\mathrm{pH}_{\mathrm{i}}=7.25-\log \frac{\left[\mathrm{C}_{\mathrm{i}}\right]}{\left[\mathrm{C}_{\mathrm{e}}\right]}
$$

The lysosomal concentration of $\mathrm{AO}\left(\mathrm{C}_{\mathrm{v}}\right)$ can be experimentally determined and the $\mathrm{pH}_{\mathrm{v}}$ can be determined in a similar manner as $\mathrm{pH}_{\mathrm{i}}$, as written in Eq. 6:

$$
\mathrm{pH}_{\mathrm{v}}=\mathrm{pH}_{\mathrm{i}}-\log \frac{\left[\mathrm{C}_{\mathrm{v}}\right]}{\left[\mathrm{C}_{\mathrm{i}}\right]}
$$

Subcellular distribution of acridine orange: In order to determine the kinetics of uptake and Pgp-mediated efflux, overall cellular and lysosomal AO concentrations, a continuous dialysis device was coupled with the spectrofluorometer (Perkin-Elmer LS 55) was applied in the experiments. The experiments were conducted in a $1 \mathrm{~cm}$ optical quartz cuvette containing $3.5 \mathrm{~mL}$ of buffer solution with $0.2 \mu \mathrm{m}$ pore diameter membrane dialysis compartment (a container of cells) placed on the top and was continuously stirred at $37^{\circ} \mathrm{C}$. The excitation beam was passed through the bottom part of the cuvette, which means only AO in supernatant was excited. The fluorescence intensity of $\mathrm{AO}$ at $527 \mathrm{~nm}$ (excited at $491 \mathrm{~nm}$ ) was measured as a function of time. After addition of AO into the system, the AO fluorescence intensity immediately increased to be $F_{0}$ following a decrease then stable. This due to amounts of $\mathrm{AO}$ was adsorbed on to the surface of the dialysis compartment. The steady state was reached in $30 \mathrm{~min}$ and the fluorescence intensity became $\mathrm{F}_{\mathrm{T}}$. Where the $\mathrm{F}_{\mathrm{T}}$ was proportional to the $\mathrm{AO}$ concentration added up to $5 \mu \mathrm{M}$.

The $\mathrm{C}_{\mathrm{T}}$ corresponds to the quantities of $\mathrm{AO}$ available for the experiment and can be determined as follows:

$$
\mathrm{C}_{\mathrm{T}}=\mathrm{C}_{\mathrm{T}}^{0} \times\left(\frac{\mathrm{F}_{0}}{\mathrm{~F}_{\mathrm{T}}}\right)
$$

where, $\mathrm{C}_{\mathrm{T}}^{0}$ and $\mathrm{F}_{0}$ are the known final $\mathrm{AO}$ concentration added into a cuvette and its corresponding fluorescence intensity, respectively.

It was confirmed that the $\mathrm{AO}$ fluorescence spectral shape and intensity did not change in the supernatant of cells. Cells $\left(10^{6}\right.$ cell. $\left.\mathrm{mL}^{-1}\right)$ were introduced into the dialysis compartment; a decrease in AO fluorescence intensity was due to the extracellular drug, which passed through the dialysis membrane and was incorporated by cells. A new steady state was attained at $60 \mathrm{~min}$, where $\mathrm{AO}$ fluorescence intensity was identified as $F_{c}$, after which $3 \mu \mathrm{M}$ monensin was added for eliminating any intracellular $\mathrm{pH}$ gradient $(\Delta \mathrm{pH})$ formation, resulting in an increase in $\mathrm{AO}$ fluorescence intensity to be $F_{\text {mon }}$. Thereafter, $0.02 \%(\mathrm{v} / \mathrm{v})$ saponin was successively added, resulting in total permeability of the plasma membrane, leading the system to reach the equilibrium state. At steady state, the free extracellular $\left(\mathrm{C}_{\mathrm{e}}\right)$ and lysosomal $\left(\mathrm{C}_{\mathrm{v}}\right)$ AO concentrations can be calculated from Eq. 8 and 9:

$$
\begin{aligned}
& \mathrm{C}_{\mathrm{e}}=\mathrm{C}_{\mathrm{T}} \times\left(\frac{\mathrm{F}_{\mathrm{c}}}{\mathrm{F}_{\mathrm{T}}}\right) \\
& \mathrm{C}_{\mathrm{v}}=\mathrm{C}_{\mathrm{T}} \times\left\{\frac{\left(\mathrm{F}_{\text {mon }}-\mathrm{F}_{\mathrm{c}}\right)}{\mathrm{F}_{\mathrm{T}}}\right\}
\end{aligned}
$$

where, $F_{m o n}$ is $\mathrm{AO}$ fluorescence intensity at a steady state after the addition of $3 \mu \mathrm{M}$ monensin. 
In the presence of $3 \mu \mathrm{M}$ monensin, any intracellular $\mathrm{pH}$ gradient $(\Delta \mathrm{pH})$ formation, in particular lysosomes, was eliminated. A new steady state was reached, where AO equilibrated between extracellular and cytoplasm compartments.

The extracellular $\left(\mathrm{C}_{\mathrm{E}}\right)$ and cytoplasm $\left(\mathrm{C}_{\mathrm{I}}\right) \mathrm{AO}$ concentrations can be determined using Eq. 10 and 11:

$$
\begin{aligned}
& \mathrm{C}_{\mathrm{I}}=\mathrm{C}_{\mathrm{T}} \times\left\{\frac{\left(\mathrm{F}_{\mathrm{T}}-\mathrm{F}_{\text {mon }}\right)}{\mathrm{F}_{\mathrm{T}}}\right\} \\
& \mathrm{C}_{\mathrm{E}}=\mathrm{C}_{\mathrm{T}} \times\left(\frac{\mathrm{F}_{\text {mon }}}{\mathrm{F}_{\mathrm{T}}}\right)
\end{aligned}
$$

The intracellular $\mathrm{AO}$ concentration $\left(\mathrm{C}_{\mathrm{i}}\right)$ at steady state, after addition of cells can be determined:

$$
\mathrm{C}_{\mathrm{i}}=\mathrm{C}_{\mathrm{e}} \times\left(\frac{\mathrm{C}_{\mathrm{I}}}{\mathrm{C}_{\mathrm{E}}}\right)
$$

The initial rate of uptake $\left(\mathrm{V}_{\mathrm{i}}^{+}\right)_{\mathrm{t}=0}$ (passive influx) was determined from the equation:

$$
\mathrm{V}_{\mathrm{i}}^{+}=\left|\left(\frac{\mathrm{dF}}{\mathrm{dt}}\right)_{\mathrm{t}=\text { cell }}\right| \cdot\left(\frac{\mathrm{C}_{\mathrm{T}}}{\mathrm{F}_{\mathrm{T}}}\right)
$$

where, $\left|\left(\frac{\mathrm{dF}}{\mathrm{dt}}\right)_{\mathrm{t}=\text { cell }}\right|$ is the slope (in absolute value) of tangent to the curve $F=f(t)$. The rate of Pgp-mediated efflux $\left(\mathrm{V}_{\mathrm{a}}\right)_{\mathrm{s}}$ of AO was determined as followed ${ }^{[12]}$ :

$$
\left(\mathrm{V}_{\mathrm{a}}\right)_{\mathrm{S}}=\mathrm{k}_{+} \times \mathrm{n} \times\left(\mathrm{C}_{\mathrm{e}}-\mathrm{C}_{\mathrm{i}}\right)
$$

Cellular uptake and the Pgp-mediated efflux of pirarubicin: The rationale and validation of experimental setup for measuring the kinetics of uptake and Pgp-mediated efflux of pirarubicin in the cells had been largely described ${ }^{[7,12,13]}$. Briefly, in a typical experiment, conducted in a $1 \mathrm{~cm}$ quartz cuvette containing $2 \mathrm{~mL}$ of HEPES-Na ${ }^{+}$buffer, $2 \times 10^{6}$ cells were incubated for $30 \mathrm{~min}$ in the presence of $10 \mathrm{mM}$ of sodium azide and in the absence of glucose, under continuous stirring at $\mathrm{pH} 7.25$ and $37^{\circ} \mathrm{C}$. The concentration of pirarubicin added to the cell suspension was varied from $0.5^{-1} 0 \mu \mathrm{M}$. The fluorescence intensity of pirarubicin at $590 \mathrm{~nm}$ (excitation at $480 \mathrm{~nm}$ ) was recorded as a function of time (model LS 55 spectrofluorometer, Perkin-Elmer). The drug influx was measured by the decrease of the fluorescence intensity that occurred during incubation with cells due to the quenching of the fluorescence after pirarubicin intercalated between the base pairs of DNA in nuclei or accumulated into acidic intracellular organelles. This methodology allowed us to measure accurately the free cytosolic concentration of pirarubicin in a steady state $\left(\mathrm{C}_{\mathrm{i}}\right)$, its initial rate of uptake $\left(\mathrm{V}_{\mathrm{i}}^{+}\right)$and the rate of Pgp-mediated efflux $\left(\mathrm{V}_{\mathrm{a}}\right)$. At the end of the experiment, intactness of cells was confirmed by trypan blue exclusion.

Flow cytofluorometric analysis: The cellular distribution of AO was characterized by using both fluorescence microscope and flow cytometer. For the assays, $2 \times 10^{6}$ cells were suspended in $2 \mathrm{~mL}$ HEPES$\mathrm{Na}^{+}$buffer $\mathrm{pH} 7.25$ at $37^{\circ} \mathrm{C}$ in the presence of various AO concentrations for $30 \mathrm{~min}$, prior to: (i) Placement on the sample holder of inverted fluorescence microscope (Nikon model TE-2000E, using a filter box model B-2E/C coupled with Nikon, digital camera model DXM 1200F) and (ii) Inject into a flow cytometer (Coulter Epics XL-MCL).

Statistic analysis: The results were presented as means \pm SD. The statistical comparisons were performed using One-way ANOVA analysis, a value of $\mathrm{p}<0.05$ was considered statistically significant.

\section{RESULTS}

Cytotoxic effects of AO and pirarubicin: Figure 1 shows the efficacy of AO and pirarubicin alone to inhibit cancer growth. Pirarubicin potently exhibited anticancer activity $\left(\mathrm{IC}_{50}=12.5 \pm 0.7 \mathrm{nM}\right)$ against drugsensitive K562 cells and was 36-fold more effective than AO. Both drugs were less cytotoxic against drugresistant sublines; the $\mathrm{IC}_{50}$ of the pirarubicin and $\mathrm{AO}$ for K562/adr was $175 \pm 35 \mathrm{nM}$ and $715 \pm 19 \mathrm{nM}$ and for

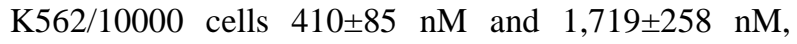
respectively. Figure 1 also shows the efficacy of cotreatment using pirarubicin or AO with $25 \mathrm{nM}$ monensin. It should be noted that $25 \mathrm{nM}$ monensin did not affect the viability of the cells. Results in the presence of $25 \mathrm{nM}$ monensin clearly showed that the $\mathrm{IC}_{50}$ of $\mathrm{AO}$ significantly decreased in both drug-sensitive and drug-resistant sublines with $\mathrm{p}<0.05$ (Fig. 1a), while no significantly affected in the series of experiments using pirarubicin (Fig. 1b) in K562 ( $\mathrm{p}=0.051$ ), $\mathrm{K} 562 / 10000(\mathrm{p}=0.48)$ and $\mathrm{K} 562 / \mathrm{adr}(\mathrm{p}=1)$ cells. 
Determination of the lysosomal concentration $\left(C_{v}\right)$ and mean influx coefficient $\left(k_{+}\right)$of AO: The interaction of AO with different intracellular organelles exhibited the particular light emission spectra which could be detected by flow cytometer such as (i) The bright green fluorescence (FL2) when AO bound to cytoskeleton protein, (ii) Dim red fluorescence (FL3) when AO accumulated in nucleus and (iii) Bright red fluorescence (FL4) when AO accumulated in lysosomes. Figure 2 shows the mean fluorescence intensity of AO bound cells; the mean red florescence intensity decreased (Fig. 2a, c and e) while that of the green fluorescence intensity increased (Fig. 2b, d and f) in the presence of $3 \mu \mathrm{M}$ monensin. These indicated that AO was liberated from lysosomes to the cytoplasm and consequently equilibrated between extra and intracellular compartments.

The quantitative measurement of lysosomal $\mathrm{AO}$ concentration $\left(\mathrm{C}_{\mathrm{v}}\right)$ was carried out using a continuous dialysis device, coupled with the spectrofluorometer. Figure 3 shows typical kinetics of uptake of AO by K562 cells. The AO fluorescence intensity decayed as a function of time and reached a steady state at $100 \mathrm{~min}$.

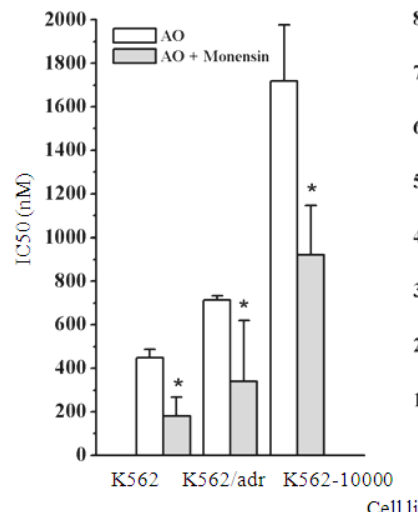

(a)

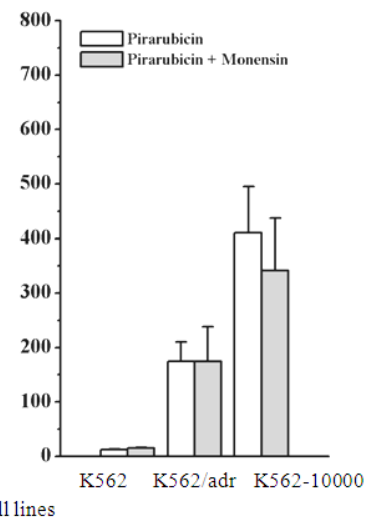

(b)
Fig. 1: Drug response pattern of MDR cell lines. Drug concentration required to inhibit cell growth by $50 \%\left(\mathrm{IC}_{50}\right)$ of $(\mathrm{a})$ : Acridine orange alone ( $\square$ ) and in combination with $25 \mathrm{nM}$ monensin ( $\square$ ); (b): Pirarubicin alone ( $\square$ ) and in combination with $25 \mathrm{nM}$ monensin ( $\square$ ). Data were mean \pm SD, $\mathrm{n}=3$. *Significantly different from co-treatment using pirarubicin or $\mathrm{AO}$ and monensin with pirarubicin or AO alone by one-way ANOVA

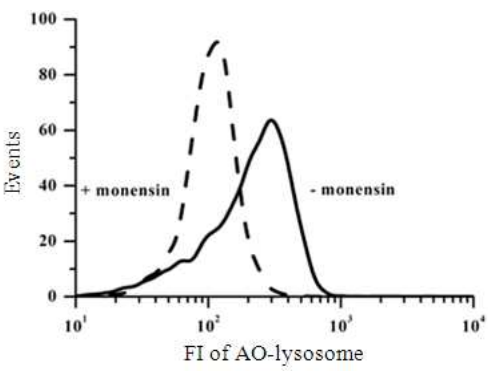

(a)

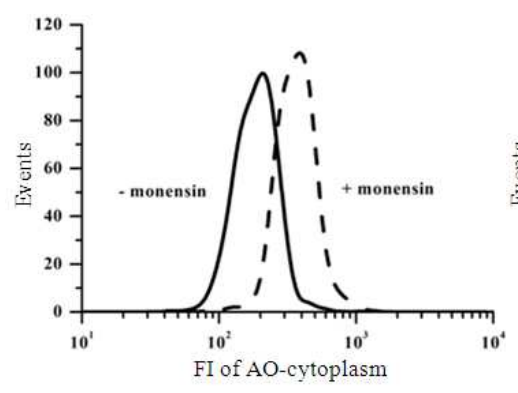

(d)

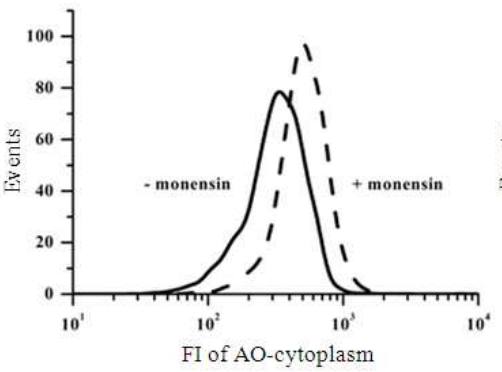

(b)

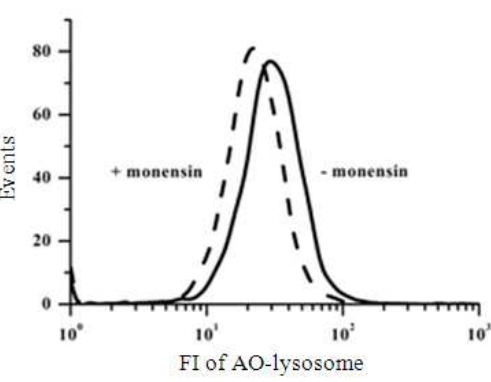

(e)

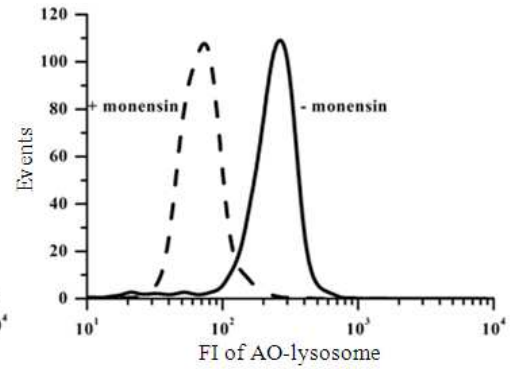

(c)

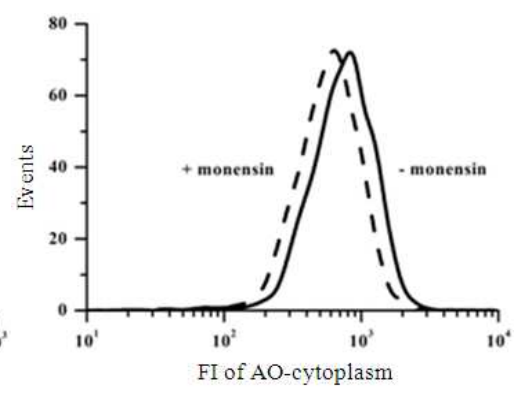

(f)

Fig. 2: Typical histograms of cell-AO bound fluorescence: Effects of $3 \mu \mathrm{M}$ monensin on (a and b): K562, (c and d): K562/adr cells (e,f) K562/10000. Cells $\left(2 \times 10^{6}\right)$ were incubated with $1 \mu \mathrm{M}$ in $2 \mathrm{~mL}$ of HEPES-Na ${ }^{+}$at $37^{\circ} \mathrm{C}$ for $30 \mathrm{~min}$. The cell-bound AO fluorescence intensity was recorded by flow cytometer without or after immediately added $3 \mu \mathrm{M}$ monensin. Each histogram was obtained from 10,000 cells 
Am. J. Applied Sci., 6 (9): 1637-1646, 2009

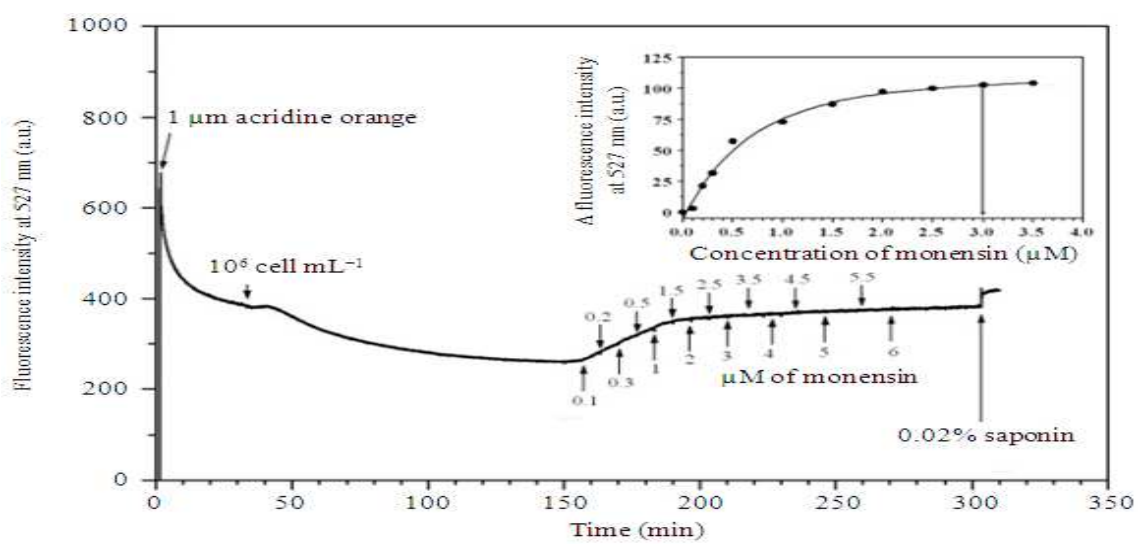

Fig. 3: Quantitative measurement of lysosomal Acridine Orange (AO) concentration [Fluorescence intensity at $527 \mathrm{~nm}$ (excited at $491 \mathrm{~nm})$ was registered as a function of time. AO $(1 \mu \mathrm{M})$ was added into the cuvette containing $3.5 \mathrm{~mL}$ of HEPES-Na ${ }^{+}$buffer at $37^{\circ} \mathrm{C}$ and vigorously stirred. At steady state, $3.5 \times 10^{6}$ cells were added, yielding a progressive decrease in fluorescence intensity then reached a new steady state and after that indicated monensin concentration was added at the same interval of time. Inset: $\Delta$ Fluorescence intensity at $527 \mathrm{~nm}$ as a function of concentration of monensin added]

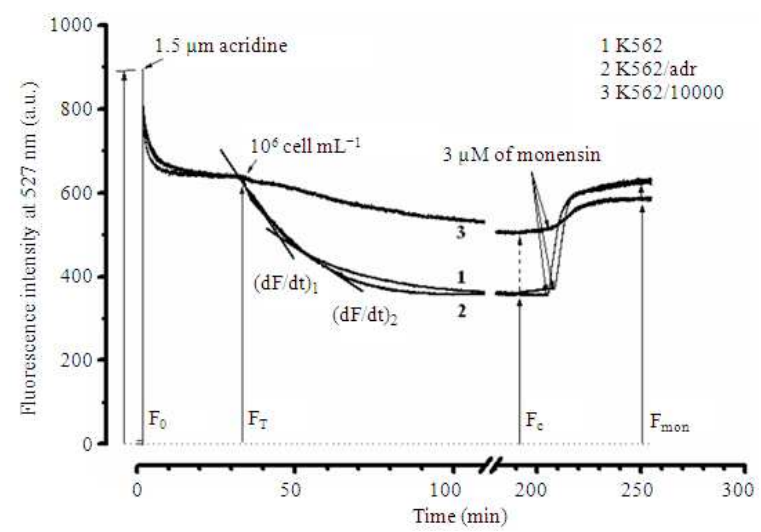

(a)

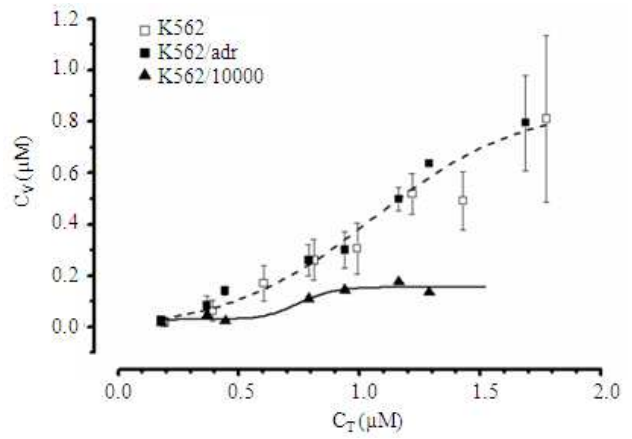

(b)

Fig. 4: (a) A typical AO uptake by three cell lines: (1) K562, (2) K562/adr and (3) K562/10000 cells, (b) intralysosmal concentration $\left(\mathrm{C}_{\mathrm{v}}\right)$ of $\mathrm{AO}$ in $(\square) \mathrm{K} 562$, ( $\left.\mathbf{\square}\right) \mathrm{K} 562 / \mathrm{adr}$ and $(\boldsymbol{\Delta}) \mathrm{K} 562 / 10000$ cell lines as a function of total concentration $\left(\mathrm{C}_{\mathrm{T}}\right)$ of $\mathrm{AO}$ added [Cells were incubated in $1 \mathrm{~cm}$ quartz cuvette containing $3.5 \mathrm{~mL}$ HEPES-Na ${ }^{+}$ buffer at $37^{\circ} \mathrm{C}$ and vigorously stirred. After the addition of $\mathrm{AO}$, the fluorescence intensity detected at $527 \mathrm{~nm}$ (excitation wavelength $491 \mathrm{~nm}$ ) was $\mathrm{F}_{0}$ and decreased progressively until the system reached a steady state $\left(\mathrm{F}_{\mathrm{T}}\right)$. Then $3.5 \times 10^{6}$ cells were added yielding a progressive decrease in fluorescence intensity at $527 \mathrm{~nm}$ which corresponded to amounts of $\mathrm{AO}$ passively diffused through plasma membrane. After the system reached a new steady state $\left(\mathrm{F}_{\mathrm{c}}\right)$, the $\mathrm{pH}$ gradient was eliminated by $3 \mu \mathrm{M}$ monensin resulting in an increased in fluorescence intensity, after which and then a new steady state was reached and characterized by the fluorescence intensity value $\mathrm{F}_{\text {mon }}$. This corresponded to liberation of the lysosomal $\mathrm{AO}\left(\mathrm{C}_{\mathrm{v}}\right)$ to cytoplasm and extra cellular compartments. The lysosomal $\left(\mathrm{C}_{\mathrm{v}}\right)$ and the initial rate of uptake $\left(\mathrm{V}_{\mathrm{i}}^{+}\right)$of $\mathrm{AO}$ can be determined using the following equation $\mathrm{C}_{\mathrm{v}}=\mathrm{C}_{\mathrm{T}} \times\left\{\frac{\left(\mathrm{F}_{\text {mon }}-\mathrm{F}_{\mathrm{c}}\right)}{\mathrm{F}_{\mathrm{T}}}\right\}$ and $\mathrm{V}_{\mathrm{i}}^{+}=\left(\frac{\mathrm{dF}}{\mathrm{dt}}\right)_{\mathrm{t}=\text { Cell }}$, repectively]

At the steady state cells were taken and injected into flow cytometer to analyze the ratio of red to green fluorescence (Fig. 2). The $\mathrm{C}_{\mathrm{v}}$ was evaluated by successive addition of incremental monensin concentration (up to $6 \mu \mathrm{M}$ ) into cells, yielding an increase in fluorescence intensity of $\mathrm{AO}$ which corresponded to the amount of 
AO released from lysosomes to cytoplasm. $\Delta$ Fluorescence intensity i.e., the difference of $\mathrm{AO}$ fluorescence intensity before and after addition of monensin, corresponding to the $\mathrm{C}_{\mathrm{v}}$, as a function of concentration of monensin added is shown in the inset of Fig. 3. The maximal $\mathrm{C}_{\mathrm{v}}$ was determined on addition of $3 \mu \mathrm{M}$ monensin.

The representative kinetics of AO uptake in K562, K562/adr and K562/10000 clls are shown in Fig. 4a. The initial rate of uptake $\left(\mathrm{V}^{+}{ }_{\mathrm{i}}\right)$ was determined in all cell lines used and was proportional to $\mathrm{C}_{\mathrm{T}}$ added. This suggested that in the concentration range used, $\mathrm{AO}$ in neutral form passively diffused across plasma membrane into cells. The mean influx coefficient of AO $\left(\mathrm{k}_{+}\right)$was obtained by linear least-square fit of data of the three cell lines and was $103 \pm 34{\mathrm{pL} . \mathrm{s}^{-1} \text {.cell }}^{-1}$. The $\mathrm{C}_{\mathrm{v}}$ was identical and reached a pseudo-plateau, when the concentration of added $\mathrm{AO}$ was above $1.75 \mu \mathrm{M}$ in K562 and K562/adr cells. However, very low quantities of $\mathrm{AO}$ were accumulated in K562/10000 cells (Fig. 4b).

Pgp-mediated efflux of pirarubicin and AO: In this study, we checked that in the range of concentrations of pirarubicin used, the accumulation in compartments other than the nucleus was negligible. Figure 5a shows that K562/adr cells contained functional Pgp $\left(\mathrm{k}_{\mathrm{a}}=2.6 \pm 0.9 \mathrm{pL} \cdot \mathrm{s}^{-1} \cdot\right.$ cell $\left.^{-1}\right)$ which extruded piraribicin out of cells about 2-fold lesser than K562/10000 cells

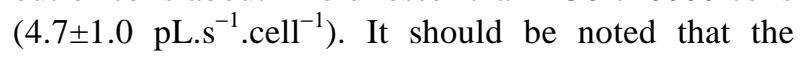
kinetics of Pgp-mediated efflux of AO determined from K562/adr cells was very low and could not be determined by this method. However, initial rate of active efflux of $\mathrm{AO}$ was easily measured from K562/10000, as indicated in Fig. 5b. In this series of experiments, saturation of initial rate of active efflux of $\mathrm{AO}$ was not obtained. The mean rate constant of active efflux $\left(\mathrm{k}_{\mathrm{ae}}\right)$ of $\mathrm{AO}$ was equal to $1,930 \pm 300$ pL. s${ }^{-1} \cdot$ cell $^{-1}$.

\section{DISCUSSION}

The results clearly showed for present study that AO was exclusively accumulated in acidic organelles, particularly lysosomes, although the nuclear compartment was reported as its potential intracellular target ${ }^{[14-16]}$. In fact, efficacy of AO improved significantly by 2 fold, when cells were incubated in the presence of $25 \mathrm{nM}$ monensin. The results should be interpreted as an addition of monensin resulted in an elimination of intracellular $\Delta \mathrm{pH}$ formation and consequently the release of $\mathrm{AO}$ from lysosomes to the cytosolic and nuclear compartment thus increased in its efficacy. The results suggested that for $\mathrm{AO}$, the sequestration of the molecule in lysosomes play a predominant mechanism of MDR phenomenon. However, for MDR cells even after elimination of $\mathrm{pH}$ gradient formation were still more resistant to AO than their corresponding parental K562 cells, indicating the Pgp-mediated efflux still plays role on the MDR phenomenon. The different observation was done for pirarubicin that is preferable accumulated on nuclear compartment. Although the function of lysosomes was inhibited in the presence of $25 \mathrm{nM}$ monensin, no additional sensitivity to pirarubicin was found for K562/adr and only slightly for K562/10000 cells. The results signified that the sequestration of pirarubicin in lysosomes did not contribute to drug resistance for K562/adr cells with lower degree of resistance and seemed to take role when MDR cells became higher resistance such as K562/10000 cells.

Earlier, we reported that the activity of anticancer drug depends on its concentration in the compartment, where its intracellular target is located and this intracellular concentration of drug directly depends on the mechanisms of its transport into the cells, in particular, the kinetic parameters ${ }^{[13]}$. Thus, the kinetic parameters of pirarubicin and $\mathrm{AO}$ for $\mathrm{K} 562$, K562/adr and K562/10000 cells were determined. Results showed that pirarubicin passively diffused through the plasma membrane of K562, K562/adr and K562/10000 cells with the same values of $\mathrm{k}_{+}=3.4 \pm 0.3 \mathrm{pL} . \mathrm{s}^{-1}$.cell ${ }^{-1[7]}$. Similar results were found for AO, which passively diffused through plasma membrane of these cell lines about 30 -fold faster than pirarubicin. It should be noted that the $\mathrm{k}_{\mathrm{a}}$ cannot be able to measure for AO but easily done with pirarubicin for K562/adr cells. This should be interpreted that the $\mathrm{k}_{+}$of $\mathrm{AO}$ is very fast, compared with the $\mathrm{k}_{\mathrm{a}}$. Under these conditions, Pgp should be saturated and the activity of Pgp per time turnover could not maintain the gradient between extra- and intracellular AO concentrations. We also showed that K562/10000 cells contained only about two-fold of functional Pgp more than K562/adr cells as shown in Fig. 5a, but the mean rate of active efflux $\left(\mathrm{k}_{\mathrm{ae}}\right)$ of $\mathrm{AO}$ was $1,930 \pm 300 \mathrm{pL} . \mathrm{s}^{-1}$.cell ${ }^{-1}$. The overall results indicated that $\mathrm{AO}$ is a poor substrate of Pgp. It was possible that its mean rate of active efflux determined for K562/10000 cells could be contributed by not only Pgp but other mechanisms that can convey numerous molecules of AO from cytoplasm to the exterior of cells per turn should be involved. This was probably a characteristic of a sequestration of $\mathrm{AO}$ in lysosomes following an enhanced exocytosis. The result was confirmed by the low $\mathrm{C}_{\mathrm{v}}$ in K562/10000 cells. 


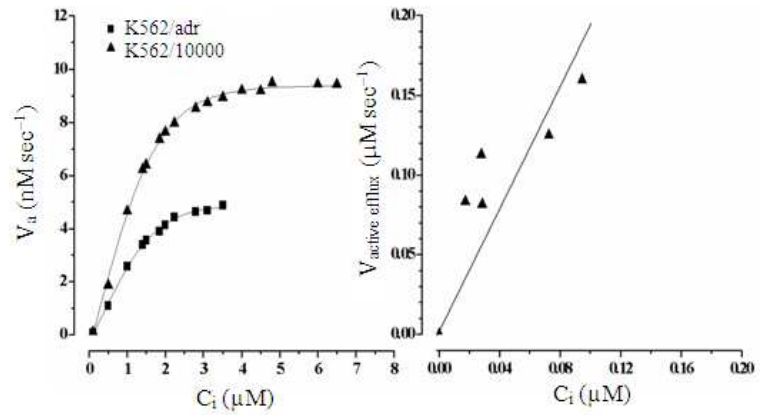

Fig. 5: Pgp-mediated efflux of (a) pirarubicin and (b) AO determined from (a) K562/adr and (A) $\mathrm{K} 562 / 10000$ cells plotted as a function of free cytosolic concentration $\left(\mathrm{C}_{\mathrm{i}}\right)$ of pirarubicin or $\mathrm{AO}$ added [Results were obtained from the series of experiments with the same conditions as Fig. 4. The transport of THP was best described by Hill's equation of enzyme kinetics, $\mathrm{V}_{\mathrm{a}}=\frac{\mathrm{V}_{\max } \cdot \mathrm{C}_{\mathrm{i}}^{\mathrm{nH}}}{\mathrm{K}_{\mathrm{m}}^{\mathrm{nH}}+\mathrm{C}_{\mathrm{i}}^{\mathrm{nH}}}$ where $\mathrm{K}_{\mathrm{m}}$ was $1.05 \pm 0.01 \mu \mathrm{M}$ and $\mathrm{V}_{\max }$ was $2.6 \pm 0.9 \mathrm{nM}^{-1}{ }^{-1}$ for $\mathrm{K} 562 / \mathrm{adr}$ and $4.7 \pm 1.0 \mathrm{nM} . \mathrm{s}^{-1}$, respectively. Hill's coefficient $(\mathrm{nH})$ was near to 1.95 . The line represents the mean value from the triplicate data]

The accumulation of $\mathrm{AO}$ in lysosomes and cytoplasm could also provide information about physico-chemical properties of microenvironments, especially the local $\mathrm{pH}$. The overall concentrations of $\mathrm{AO}$ in each compartment were measured in molar units (global conc.) for all series of experiments. The $\mathrm{C}_{\mathrm{i}}$ and $\mathrm{C}_{\mathrm{v}}$ allowed us to determine $\mathrm{pH}_{\mathrm{i}}$ and $\mathrm{pH}_{\mathrm{v}}$ as shown in Fig. 6. The $\mathrm{pH}_{\mathrm{i}}$ for all cell lines used in these experiments was about 7.25 (Fig. 6a). The $\mathrm{pH}_{\mathrm{v}}$ as a function of $\mathrm{C}_{\mathrm{v}}$ is indicated in Fig. 6b. In K562 and K562/adr cells, the $\mathrm{pH}_{\mathrm{v}}$ increased with $\mathrm{C}_{\mathrm{v}}$ then reached a plateau when $\mathrm{C}_{\mathrm{v}}$ was equal to $0.5 \mu \mathrm{M}$, where $\mathrm{pH}_{\mathrm{v}}$ about 7.2 closely to $\mathrm{pH}_{\mathrm{i}}$. These results suggested that either the $\mathrm{H}^{+}$-ATPase pump may be saturated or the maximum volume of these organelles could be attained when there was enough concentration of the basic molecule inside. The initial $\mathrm{pH}_{\mathrm{v}}$ (without $\mathrm{AO}$ inside) was calculated from the function of $\mathrm{pH}_{\mathrm{v}}=\int\left(\mathrm{C}_{\mathrm{v}}\right)$ using a non-linear plot (Boltzman's model) for K562 and K562/adr cell lines and was equal to 6.30. Similar results were obtained in K562/10000 cells but no saturation of $\mathrm{pH}_{\mathrm{v}}$ was obtained because of too low $\mathrm{C}_{\mathrm{v}}$; the data were linearly least-square fitted and the initial $\mathrm{pH}_{\mathrm{v}}$ value was about 5.70. Both an acidified of $\mathrm{pH}_{\mathrm{v}}$ and alkalinized of $\mathrm{pH}_{\mathrm{i}}$ of MDR cells compared with its corresponding drug-sensitive cells were also reported in literatures ${ }^{[5,17-21]}$. For example,
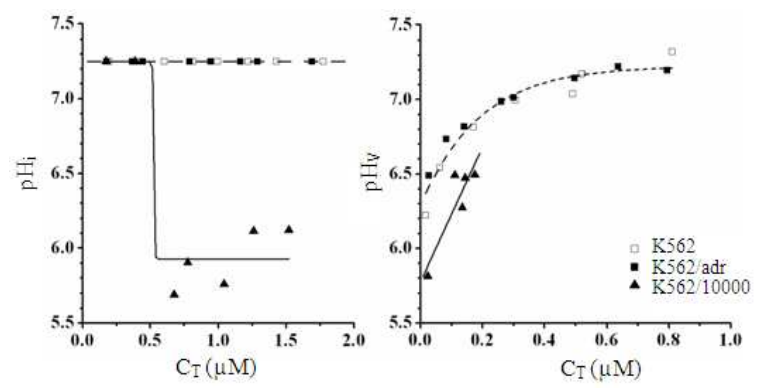

Fig. 6: Calculated intracellular (a) and intraluminal (b) $\mathrm{pH}$ of lysosomes of (口) K562, (匹) K562/adr and ( $\Delta$ ) K562/10000 cell lines as a function of concentration of AO [data from series of experiments of Fig. 4]

$\Delta \mathrm{pH}$ was found to be 1.2 and 0.3 unit in MDR $\left(\mathrm{pH}_{\mathrm{i}}=7.1 \pm 0.025\right)$ and sensitive MCF-7 cells $\left(\mathrm{pH}_{\mathrm{i}}=6.8 \pm 0.025\right)$ respectively ${ }^{[19]}$. In addition, acidification of lysosome was also reported in drugresistant cells ${ }^{[5]}$.

The application of $\mathrm{AO}$, an intrinsic fluorescent basic molecule as molecular probe, allowed us to monitor the spontaneous changes in $\mathrm{pH}_{\mathrm{i}}$ during $\mathrm{AO}$ incorporation into cells (Fig. 6a). Results suggested that uptake of $\mathrm{AO}$ stimulated acidification of $\mathrm{pH}_{\mathrm{i}}$ in MDR cells with high degree of resistance. It was important to note that $\mathrm{AO}$ did not induce any $\mathrm{pH}_{\mathrm{i}}$ change in K562/adr cell. Recently, we reported that in $\mathrm{K} 562 / 10000$ cells, the $\mathrm{K}^{+} / \mathrm{H}^{+}$antiporter exchanger could be activated by pirarubicin transport, leading to an acidification of $\mathrm{pH}_{\mathrm{i}}^{[7]}$. In fact, the maintenance of $\mathrm{pH}_{\mathrm{i}}$ within a narrow physiological range is vital to normal cell function. Nevertheless, the intracellular free $\mathrm{H}^{+}$ could vary in response to different stimuli. Evidences indicated that intracellular protons could serve as a second messenger in regulating multiple cellular functions $^{[22,23]}$.

\section{CONCLUSION}

The present study demonstrated that by using the same cell lines and methodology, but different molecular probes such as AO and pirarubicin, different predominant cellular defense processes were elucidated. The predominant mechanism of MDR phenomenon is depended totally on the nature of the molecular probe used. In fact, the role of Pgp-mediated efflux of cytotoxic drug out of the cell conferring lower available intracellular concentration, thereby lower efficiency can be clearly demonstrated using pirarubicin. The drug sequestration in lysosomes was also a major cause of 
lowering available intracellular concentration of the drug which provided the advantages for the MDR cells, particularly K562/10000 cells, to survive prolonged exposure to cytotoxic agents and thus to contribute to chemotherapeutic resistance.

\section{ACKNOWLEDGEMENT}

This study was partly supported by the Royal Thai Government and the Royal Golden Jubilee program (RGJ). SD thanks the Royal Golden Jubilee Ph.D. program and The French embassy in Bangkok for financial support.

\section{REFERENCES}

1. Gottesman, M.M., T. Fojo and S.E. Bates, 2002. Multidrug resistance in cancer: Role of ATPdependent transporters. Nat. Rev. Cancer, 2: 48-58. DOI: $10.1038 / \mathrm{nrc} 706$

2. Young, L.C., B.G. Campling, S.P. Cole, R.G. Deeley and J.H. Gerlach, 2001. Multidrug resistance proteins MRP3, MRP1 and MRP2 in lung cancer: Correlation of protein levels with drug response and messenger RNA levels. Clin Cancer Res., 7: 1798-1804.

http://clincancerres.aacrjournals.org/cgi/content/ful $1 / 7 / 6 / 1798$

3. Rybarova, S., M. Hajdukova, I. Hodorova, M. Kocisova and A. Boor et al., 2004. Expression of the Multidrug Resistance-associated Protein 1 (MRP1) and the Lung Resistance-related Protein (LRP) in human lung cancer. Neoplasma, 51: 169-174. http://neoplasma.aepress.sk/casopisy/01AV.php?fil e=2004_03169.pdf

4. Miraglia, E., D. Viarisio, C. Riganti, C. Costamagna, D. Ghigo and A. Bosia, 2005. $\mathrm{Na}+\mathrm{H}+$ exchanger activity is increased in doxorubicin-resistant human colon cancer cells and its modulation modifies the sensitivity of the cells to doxorubicin. Int. J. Cancer, 115: 924-929. DOI: 10.1002/ijc.20959

5. Altan, N., Y. Chen, M. Schindler and S.M. Simon, 1998. Defective acidification in human breast tumor cells and implications for chemotherapy. J. Exp. $\quad$ Med., 187: 1583-1598. http://www.jem.org/cgi/content/full/187/10/1583

6. Larsen, A.K., A.E. Escargueil and A. Skladanowski, 2000. Resistance mechanisms associated with altered intracellular distribution of anticancer agents. Pharmacol. Ther., 85: 217-229. DOI: 10.1016/S0163-7258(99)00073-X
7. Meesungnoen, J., J.P. Jay-Gerin and S. Mankhetkorn, 2002. Relation between MDR1 mRNA levels, resistance factor and the efficiency of Pglycoprotein-mediated efflux of pirarubicin in multidrug-resistant K562 sublines. Can. J. Physiol. Pharmacol., 80: 1054-1063. DOI: 10.1139/y02-132

8. Forgac, M., 1998. Structure, function and regulation of the vacuolar $(\mathrm{H}+)$-ATPases. FEBS Lett., 440: 258-263. DOI: 10.1016/S00145793(98)01425-2

9. Huang, S.S., H.A. Koh and J.S. Huang, 1997. Suramin enters and accumulates in low $\mathrm{pH}$ intracellular compartments of $\mathrm{V}$-sis-transformed NIH 3T3 cells. FEBS Lett., 416: 297-301. DOI: 10.1016/S0014-5793(97)01213-1

10. Vercesi, A.E. and R. Docampo, 1996. Sodiumproton exchange stimulates $\mathrm{Ca}_{2}+$ release from acidocalcisomes of Trypanosoma brucei. Biochem J., 315: 265-270. http://www.biochemj.org/bj/315/0265/bj3150265.htm

11. Slapak, C.A., J.M. Lecerf, J.C. Daniel and S.B. Levy, 1992. Energy-dependent accumulation of daunorubicin into subcellular compartments of human leukemia cells and cytoplasts. J. Biol. Chem., 267: 10638-10644. http://www.jbc.org/cgi/reprint/267/15/10638

12. Tarasiuk, J., J. Foucrier and A. Garnier-Suillerot, 1993. Cell cycle dependent uptake and release of anthracycline by drug-resistant and drug-sensitive human leukaemic K562 cells. Biochem. Pharmacol., 45: 1801-1808. DOI: 10.1016/00062952(93)90436-Z

13. Mankhetkorn, S., F. Dubru, J. Hesschenbrouck, M. Fiallo and A. Garnier-Suillerot, 1996. Relation among the resistance factor, kinetics of uptake and kinetics of the P-glycoprotein-mediated efflux of doxorubicin, daunorubicin, 8-(S)-fluoroidarubicin and idarubicin in multidrug-resistant K562 cells. Mol. Pharmacol., 49: 532-539. http://molpharm.aspetjournals.org/cgi/content/abstr act/49/3/532

14. Kusuzaki, K., G. Minami, H. Takeshita, H. Murata and S. Hashiguchi et al., 2000. Photodynamic inactivation with acridine orange on a multidrugresistant mouse osteosarcoma cell line. Jap. J. Cancer Res., 91: 439-445. DOI: 10.1111/j.13497006.2000.tb00964.x

15. Dobrucki, J. and Z. Darzynkiewicz, 2001. Chromatin condensation and sensitivity of DNA in situ to denaturation during cell cycle and apoptosis-a confocal microscopy study. Micron, 32: 645-652. DOI: $10.1016 / \mathrm{S} 0968-$ 4328(00)00069-X 
16. Grunwald, D., 1993. Flow cytometry and RNA studies. Biol. Cell 78: 27-30. DOI: 10.1016/02484900(93)90111-Q

17. Dell'Antone, P. and L. Piergallini, 1997. The antineoplastic drug lonidamine interferes with the acidification mechanism of cell organelles. Biochim. Biophys. Acta, 1358: 46-52. DOI: 10.1016/S0167-4889(97)00049-9

18. Ferderick, C.A., L.D. Williams, G. Ughetto, G.A. van der Marel, J.H. van Boom, A. Rich and A.H.J. Wang, 1990. Structural comparison of anticancer drug-DNA complexes: Adriamycin and daunomycin. Biochem. J., 29: 2538-2549. http://www.ncbi.nlm.nih.gov/pubmed/2334681

19. Schindler, M., S. Grabski, E. Hoff and S.M. Simon, 1996. Defective $\mathrm{pH}$ regulation of acidic compartments in human breast cancer cells (MCF7) is normalized in adriamycin-resistant cells (MCF-7adr). Biochem. J., 35: 2811-2817 http://cat.inist.fr/?aModele $=$ afficheN\&cpsidt $=1091$ 2329

20. Belhoussine, R., H. Morjani, S. Sharonov, D. Ploton and M. Manfait, 1999. Characterization of intracellular $\mathrm{pH}$ gradients in human multidrugresistant tumor cells by means of scanning microspectrofluorometry and dual-emission-ratio probes. Int. J. Cancer, 81: 81-89. DOI: 10.1021/bi952234e
21. Roepe, P.D., L.Y. Wei, J. Cruz and D. Carlson, 1993. Lower electrical membrane potential and altered $\mathrm{pHi}$ homeostasis in multidrug-resistant (MDR) cells: Further characterization of a series of MDR cell lines expressing different levels of Pglycoprotein. Biochem. J., 32: 11042-11056. http://www3.interscience.wiley.com/journal/66500 142/abstract

22. Filosa, J.A., J.B. Dean and R.W. Putnam, 2002. Role of intracellular and extracellular $\mathrm{pH}$ in the chemosensitive response of rat locus coeruleus neurones. J. Physiol., 541: 493-509. DOI: 10.1113/jphysiol.2001.014142

23. Berger, M.G., C. Vandier, P. Bonnet, W.F. Jackson and N.J. Rusch, 1998. Intracellular acidosis differentially regulates $\mathrm{KV}$ channels in coronary and pulmonary vascular muscle. Am. J. Physiol., 275: H1351-1359.

http://ajpheart.physiology.org/cgi/content/full/275/ 4/H1351 